\title{
Aspek Legal Spirit Undang-Undang Nomor 23 Tahun 2004 Tentang Penghapusan Kekerasan Dalam Rumah Tangga
}

\author{
Elias Zadrach Leasa \\ Fakultas Hukum Universitas Negeri Lampung, Lampung, Indonesia \\ E-mail: eliaszleasa72@gmail.com
}

\begin{abstract}
Families are places where everyone in the family feels safe and comfortable from acts o violence, but in reality violence also accurs whitin the family. The enactment of Law No. 23 of 2004 on the abolition of domestic violence (hereinafter referred to as the Law of Domestic Violence) aims to prevent all forms of domestic violence, protect domestic violence victims, prosecute domestic violence perpetrators, and maintain wholeness harmonious and prosperous households. In handling it is sometimes resolved peacefully. This raises the question of whether the Law on Elimination of Domestic Violence has guaranteed the settlement of Domestic Violence according to its objectives? All forms of violence against women and children constitute a violation of human rights, so it is necessary to be protected by their dignity and dignity and guaranteed their right to life in accordance with their nature and nature without discrimination. The Criminal Act contained in Article 5 of the Act states that prohibited violence is physical violence, psychological violence, sexual violence, or neglect of the household. Many cases of domestic violence are reported but not a few are repealed by the victim for various reasons, such as still loving the perpetrator, and the perpetrator is the breadwinner in the household. The resolution of cases of domestic violence is also up to the court's decision, but this certainly brings the consequences of the objective of the Law on Elimination of Domestic Violence. Despite all forms of prevention of domestic violence, protecting the victim, prosecuting the perpetrator is reached but if the case is passed on to the court decision whether the goal of maintaining a harmonious and prosperous household unity can be achieved. The resolution of domestic violence requires the wisdom of the Law Enforcers (Police, Prosecutors, Judges).
\end{abstract}

Keywords: Legal Spirit, Violence, Household.

\section{A. PENDAHULUAN.}

Setiap orang mempunyai kehendak bebas yang lahir dari niat yang suci untuk melangsungkan perkawinan. Perkawinan merupakan sarana untuk melangsungkan keturunan. Perkawinan merupakan ikatan lahir dan batin antara seorang pria dan seorang wanita sebagai suami istri dengan tujuan membentuk keluarga atau 
rumah tangga yang bahagia dan kekal berdasarkan Ketuhanan Yang Maha Esa. Namun kadang dalam membina ikatan lahir dan batin itu ada saja masalah yang timbul baik dalam rumah tangga maupun di luar rumah tangga tersebut.

Keluarga merupakan lingkungan sosial pertama yang dikenal oleh manusia. Dalam keluarga, manusia belajar untuk mulai berinteraksi dengan orang lain. Oleh karena itulah umumnya orang banyak menghabiskan waktunya dalam lingkungan keluarga. Sekalipun keluarga merupakan lembaga sosial yang ideal guna menumbuhkembangkan potensi yang ada pada setiap individu, dalam kenyataannya keluarga sering kali menjadi wadah bagi munculnya berbagai kasus penyimpangan atau aktivitas ilegal lain sehingga menimbulkan kesengsaraan atau penderitaan, yang dilakukan oleh anggota keluarga satu terhadap anggota keluarga lainnya seperti penganiayaan, pemerkosaan, pembunuhan. Situasi inilah yang lazim disebut dengan istilah Kekerasan dalam Rumah Tangga.

Kekerasan dalam rumah tangga telah menjadi wacana tersendiri dalam keseharian. Pada umumnya, dalam struktur kekerabatan di Indonesia kaum laki-laki ditempatkan pada posisi dominan, yakni sebagai kepala keluarga. Dengan demikian, bukan hal yang aneh apabila anggota keluarga lainnya menjadi sangat tergantung kepada kaum laki-laki. Posisi laki-laki yang demikian superior sering kali menyebabkan dirinya menjadi sangat berkuasa di tengah-tengah lingkungan keluarga. Bahkan pada saat laki-laki melakukan berbagai penyimpangan kekerasan terhadap anggota keluarga lainnya dimana perempuan dan juga anak menjadi korban utamanya tidak ada seorang pun dapat menghalanginya.

Masalah yang sering timbul dan mengakibatkan kekerasan merupakan hal yang sangat peka karena menyangkut masalah keluarga, namun perempuan sendiri engan untuk membicarakannya.
Tindak kekerasan terhadap perempuan merupakan masalah bersama. ${ }^{1}$

Masalah yang timbul itu terkadang dapat diselesaikan namun ada juga yang tidak terselesaikan. Masalah yang tidak terselesaikan ini akan mempunyai potensi terhadap kekerasan maupun ancaman kekerasan dalam rumah tangga tersebut. Kata 'kekerasan' menjadi salah satu kata yang lazim dipergunakan untuk menjelaskan beberapa persoalan yang terkait dengan perlakuan atau tindakan yang dipandang tidak menyenangkan, tidak manusiawi, bertantangan dengan norma/nilai tertentu atau hukum, atau sesuatu yang bertentangan dengan kehendak diri kita.

Korban dari kekerasan dalam rumah tangga yang paling dominan adalah perempuan, untuk itu dalam memberikan perlindungan kepada perempuan maka dikeluarkannya Undang-undang Nomor 23 Tahun 2004 tentang Penghapusan Kekerasan Dalam Rumah Tangga (selanjutnya disingkat UUPKDRT). Kekerasan dalam Rumah Tangga (selanjutnya disingkat KDRT) adalah setiap perbuatan terhadap seseorang terutama perempuan, yang berakibat timbulnya kesengsaraan atau penderitaan secara fisik, seksual, psikologis, dan/atau penelantaran rumah tangga termasuk ancaman untuk melakukan perbuatan, pemaksaan, atau perampasan kemerdekaan secara melawan hukum dalam lingkup rumah tangga. Sedangkan kekerasan yang terjadi dalam rumah tangga dikategorikan dalam kekerasan fisik, kekerasan psikis, kekerasan seksual dan penelantaran rumah tangga. Hal ini dapat terjadi karena beberapa factor pemicu/pendorong misalnya masalah keuangan, cemburu, masalah anak, masalah orang tua, saudara, sopan santun,

1 Soeroso, Moerti Hadiati. (2010). Kekerasan Dalam Rumah Tanggga (Dalam Perspektif Yuridis-Kriminologi), Jakarta: Sinar Grafika, h. 1 
masa lalu, salah paham. ${ }^{2}$

Dalam upaya penanggulangan kekerasan dalam rumah tangga dengan menggunakan sanksi (hukum) pidana merupakan cara yang paling tua, setua peradaban manusia itu sendiri, bahkan ada yang mengatakan bahwa: "hukum pidana merupakan the older philosophy of crime control "3. Sampai saat ini pun, hukum pidana masih digunakan dan "diandalkan" sebagai salah satu sarana politik kriminal. ${ }^{4}$

Hal tersebut dapat dilihat dari adanya ancaman pidana pada hampir setiap produk perundang-undangan yang dikeluarkan oleh badan legislatif negara ini, meskipun produk perundang-undangan tersebut tidak termasuk dalam perundang-undangan yang tidak mengatur secara spesifik tentang suatu tindak pidana.

Kondisi demikian membawa konsekuensi terhadap Sistem Peradilan Pidana Indonesia dalam menangani tindak kejahatan hampir seluruhnya selalu berakhir di penjara. Dalam UUPKDRT, pada Pasal 4 merupakan tujuan dari penghapusan kekerasan dalam rumah tangga, yakni :

a) mencegah segala bentuk kekerasan dalam rumah tangga;

b) melindungi korban kekerasan dalam rumah tangga;

c) menindak pelaku kekerasan dalam rumah tangga; dan

d) memelihara keutuhan rumah tangga yang harmonis dan sejahtera.

Pasal tersebut merupakan tujuan diadakannya undang-undang

2 Gosita, Arief. (1993). Masalah Korban Kejahatan, Jakarta : Akademika Pressindo, h. 7.

3 Packer, Herbert L. (1968). The Limits of Criminal Sanction, h. 3.

4 Arief, Barda Nawawi. (1998). Beberapa Aspek Kebijakan Penegakan dan Pengembangan Hukum Pidana, Bandung: Citra Aditya Bakti, h. 39. penghapusan kekerasan dalam rumah tangga, namun yang sering terjadi adalah mencegah segala bentuk kekerasan dalam rumah tangga, melindungi korban kekerasan dalam rumah tangga, menindak pelaku kekerasan dalam rumah tangga dapat terwujud tetapi untuk poin $\mathrm{d}$, yakni memelihara keutuhan rumah tangga yang harmonis dan sejahtera tidak dapat diwujudkan. Padahal keempat tujuan dalam undang-undang ini adalah merupakan satu kesatuan, sehingga harus dipahami benar bahwa bukan saja mencegah korban, menindak pelaku, melindungi korban kekerasan dalam rumah tangga tetapi untuk memelihara keutuhan rumah tangga yang harmonis dan sejatera.

UUPKDRT diharapkan dapat dijadikan sebagai perangkat hukum yang memadai, yang didalamnya antara lain mengatur mengenai pencegahan, perlindungan terhadap korban, dan penindakan terhadap pelaku KDRT, dengan tetap menjaga keutuhan demi keharmonisan keluarga. Apa yang sesungguhnya ingin dicapai oleh undang-Undang ini adalah meminimalisir tindak pidana KDRT dan pada akhirnya adalah terwujudnya posisi yang sama dan sederajat di antara sesama anggota keluarga.

Berdasarkan latar belakang diatas maka penulis menggangkat permasalah untuk dikaji dan dianalisis sebagai berikut : apakah Undang-undang Penghapusan Kekerasan Dalam Rumah Tangga telah menjamin penyelesaian Kekerasan Dalam Rumah Tangga sesuai tujuannya.?

\section{B. PEMBAHASAN}

\section{Perlindungan Perempuan Dan Anak}

Setiap warga Negara berhak untuk bebas dari penyiksaan atau perlakukan yang merendahkan derajat martabat manusia serta berhak mendapatkan rasa aman dan bebas dari segala bentuk 
kekerasan. Segala bentuk tindak kekerasan terhadap perempuan dan anak merupakan pelanggaran hak asasi manusia sehingga perlu dilindungi harga diri dan martabatnya serta dijamin hak hidupnya sesuai dengan fitrah dan kodratnya tanpa diskriminasi kekerasan terhadap perempuan dan anak terus meningkat, sehingga diperlukan upaya perlindungan.

Perlindungan yang dimaksudkan disini adalah perlindungan hukum yakni perlindungan yang diberikan oleh Pemerintah melalui perangkat hukumnya seperti Peraturan Perundang-undangan. Perlindungan kepada perempuan merupakan perjuangan emansipasi wanita setelah kemerdekaan, telah dituangkan dalam beraneka bentuk, baik berupa perundang-undangan maupun yurisprudensi Mahkamah Agung dan hal ini membuktikan bahwa kedudukan kaum wanita di mata hukum Indonesia ini menunjukkan kemajuan yang sangat pesat dan positif. ${ }^{13}$ Demikian juga perlindungan terhadap anak yang merupakan amanah sekaligus karunia Tuhan Yang Maha Esa, yang senantiasa harus kita jaga karena dalam dirinya melekat harkat, martabat, dan hak-hak sebagai manusia yang harus dijunjung tinggi.

Perlindungan hukum yang diberikan karena perempuan dan anak rentan terhadap kejahatan yang terjadi, maraca menjadi korban kejahatan yang pada dasarnya merupakan pihak yang paling menderita dalam suatu tindak pidana, justru tidak memperoleh perlindungan sebanyak yang diberikan oleh Undang-Undang kepada pelaku kejahatan sebagaimana dikemukakan oleh Andi Hamzah bahwa "Dalam membahas hukum acara pidana khususnya yang berkaitan dengan hakhak asasi manusia, ada kecenderungan untuk mengupas hal-hal yang berkaitan

13 Situmorang, Victor. (1988). Kedudukan Wanita Di Mata Hukum, Jakarta: Bina Aksara, h. 10 dengan hak-hak tersangka tanpa memperhatikan pula hak-hak korban ${ }^{14}$."

Perlindungan hukum korban

kejahatan sebagai bagian dari perlindungan masyarakat, dapat diwujudkan dalam berbagai bentuk, seperti melalui pemberian restitusi dan kompensasi, pelayanan medis, dan bantuan hukum. ${ }^{15}$ Ganti rugi adalah sesuatu yang diberikan kepada pihak yang menderita kerugian sepadan dengan memperhitungkan kerusakan yang dideritanya. ${ }^{16}$

Perbedaan antar kompensasi dan restitusi adalah "kompensasi timbul dari permintaan korban, dan dibayar oleh masyarakat atau merupakan bentuk pertanggungjawaban masyarakat atau negara (The responsible of the society), sedangkan restitusi lebih bersifat pidana, yang timbul dari putusan pengadilan pidana dan dibayar oleh terpidana atau merupakan wujud pertanggungjawaban terpidana." 17

Perlindungan korban dapat mencakup bentuk perlindungan yang bersifat abstrak (tidak langsung) maupun yang konkret (langsung). Perlindungan yang abstrak pada dasarnya merupakan bentuk perlindungan yang hanya bisa dinikmati atau dirasakan secara emosional (psikis), seperti rasa puas (kepuasan). Sementara itu, perlindungan yang kongkret pada dasarnya merupakan bentuk perlindungan yang dapat dinikmati secara nyata, seperti pemberian yang berupa atau bersifat materii maupun non-materi. Pemberian yang bersifat

14 Hamzah, Andi. (1986). Perlindungan Hak-Hak Asasi Manusia dalam Kitab Undang-Undang Hukum Acara Pidana, Bandung: Binacipta, h. 33

15 Mansur, Dikdik. M. Arief. (2007). Urgensi Perlidungan Korban Kejahatan Antara Norma dan Realita, Jakarta: RajaGrafindo Persada, h. 31.

16 Bentham, Jeremy. (2006). Teori Perundang-Undangan Prinsip-Prinsip Legislasi, Hukum Perdata dan Hukum Pidana, Bandung: Penerbit Nusamedia \& Penerbit Nuansa, h. 316.

${ }^{17}$ Schafer, Stephen. (1968). The Victim and Criminal, Random House, New York, h. 112. 
materi dapat berupa pemberian kompensasi atau restitusi, pembebasan biaya hidup atau pendidikan. Pemberian perlindungan yang bersifat non-materi dapat berupa pembebasan dari ancaman, dari pemberitaan yang merendahkan martabat kemanusiaan.

Menurut Barda Nawawi Arief menyatakan bahwa pengertian perlindungan korban dapat dilihat dari dua makna, yaitu: ${ }^{18}$

a) dapat diartikan sebagai "perlindungan hukum untuk tidak menjadi korban tindak pidana", (berarti perlindungan HAM atau kepentingan hukum seseorang).

b) dapat diartikan sebagai "perlindungan untuk memperoleh jaminan/santunan hukum atas penderitaan/ kerugian orang yang telah menjadi korban tindak pidana", (jadi identik dengan "penyantunan korban"). Bentuk santunan itu dapat berupa pemulihan nama baik (rehabilitasi), pemulihan keseimbangan batin (antara lain dengan pemaafan), pemberian ganti rugi (restitusi, kompensasi, jaminan/santunan kesejahteraan sosial), dan sebagainya.

Dalam konsep perlindungan hukum terhadap korban kejahatan, terkandung pula beberapa asas hukum yang memerlukan perhatian. Hal ini disebabkan dalam konteks hukum pidana, sebenarnya asas hukum harus mewarnai baik hukum pidana materiil, hukum pidana formil, maupun hukum pelaksanaan pidana. ${ }^{19}$

Adapun asas-asas yang dimaksud sebagai berikut: ${ }^{20}$

1) Asas manfaat.

18 Arief, Barda Nawawi. (2007). Masalah Penegakan Hukum dan Kebijakan Hukum Pidana dalam Penanggulangan Kejahatan, Jakarta: Kencana, h. 61.

${ }^{19}$ Gosita, Arif. Op. Cit, h. 50.

${ }^{20}$ Mansur, Dikdik. M. Arief Op.cit, h. 164.
Perlindungan korban tidak hanya ditujukan bagi tercapainya kemanfaatan (baik materiil maupun spiritual) bagi korban kejahatan, tetapi juga kemanfaatan bagi masyarakat secara luas, khususnya dalam upaya mengurangi jumlah tindak pidana serta menciptakan ketertiban masyarakat.

2) Asas keadilan.

Penerapan asas keadilan dalam upaya melindungi korban kejahatan tidak bersifat mutlak karena hal ini dibatasi pula oleh rasa keadilan yang harus juga diberikan pada pelaku kejahatan.

3) Asas keseimbangan.

Karena tujuan hukum di samping memberikan kepastian dan perlindungan terhadap kepentingan manusia, juga untuk memulihkan keseimbangan tatanan masyarakat yang terganggu menuju pada keadaan yang semula (restitutio in integrum), asas keseimbangan memperoleh tempat yang penting dalam upaya pemulihan hak-hak korban.

4) Asas kepastian hukum.

Asas ini dapat memberikan dasar pijakan hukum yang kuat bagi aparat penegak hukum pada saat melaksanakan tugasnya dalam upaya memberikan perlindungan hukum pada korban kejahatan.

\section{Bentuk - Bentuk Kekerasan Perempuan Dalam UUPKDRT}

Secara etimologis kata "tindak pidana" berasal dari kata "Strafbaar feit" (Belanda) dengan pengertian perbuatan yang dilarang oleh peraturan hukum pidana dan tentu saja dikenakan sanksi pidana bagi siap saja yang melanggar.

Ada yang menterjemahkan "Strafbaar feit" dengan istilah-istilah sebagai berikut: 
1) Peristiwa pidana;

2) Perbuatan pidana;

3) Perbuatan yang boleh dihukum; dan

4) Pelanggaran pidana.

Moeljatno, mengunakan istilah perbuatan pidana sebagai terjemahan dari strafbaar feit dengan alasan dan pertimbangan-pertimbangan sebagai berikut: ${ }^{26}$

1) kalau untuk recht, sudah lazim dipakai istilah: hukum, maka dihukum lalu berarti; berecht, diadili, yang sama sekali tidak mesti berhubungan dengan straf, pidana; karena perkara-perkara perdata-pun diberecht, diadili. Maka beliau memilih untuk terjemahan strafbaar adalah istilah Pidana sebagai singkatan dari Yang Dapat Dipidana.

2) Perkataan perbuatan sudah lazim dipergunakan dalam percakapan sehari-hari seperti; perbuatan tak senonoh, perbuatan jahat dan sebagainya dan juga sebagai istilah teknis, seperti: perbuatan melawan hukum (onrechtmatige daad). Perkataan perbuatan berarti dibuat oleh seseorang dan menunjuk baik pada yang melakukan maupun pada akibatnya. Sedangkan perkataan peristiwa tidak menunjukkan, bahwa yang menimbulkannya adalah "handeling" atau "gedraging" seseorang, mungkin juga hewan atau alam. Dan perkataan tindak berarti langklah dan baru dalam bentuk tindak tanduk atau tingkah laku.

Utrecht menganjurkan pemakaian istilah peristiwa pidana, karena istilah peristiwa itu meliputi perbuatan (handelen atau doen, positif) atau

26 Moeljatno. (1955). Perbuatan Pidana dan Pertanggungjawaban Pidana, Yogyakarta: Badan Penerbit Gajah Mada. h. 8. melainkan (verzuim atau nalaten atau niet-doen, negatif) maupun akibatnya. Satocihid Kartanegara menganjurkan peemakaian istilah tindak pidana, karena istilah ini tindak (tindakan), mencakup pengertian melakukan atau berbuat (actieve handeling) dan/atau pengertian tidak melakukan, tidak berbuat, tidak melakukan suatu perbutan (passieve handeling). ${ }^{27}$

Mr. R. Tresna, mengatakan sungguh tidak mudah untuk memberikan suatu defenisi yang tepat, Beliau mengatakan bahwa peristiwa pidana itu ialah sesuatu perbuatan manusia, yang bertentangan dengan Undang-undang atau peraturan-peraturan lainnya, terhadap perbuatan mana diadakan tindakan penghukuman. Beliau menerangkan bahwa perumusan tersebut jauh dari sempurna,karena dalam uraian beliau selanjutnya diutarakan bahwa sesuatu perbuatan itu baru dapat dipandang sebagai peristiwa pidana, apabila telah memenuhi segala syarat yang diperlukan. ${ }^{28}$

Tindak pidana secara yuridis juga disebut dengan delik. Tindak pidana atau delik adalah perbuatan yang dapat diancam pidana bagi pelakunya. Tindak pidana mempunyai dua segi, yaitu :

1) Segi subyektif, adalah yang berhubungan atau berkenan dengan prilaku. (subyek tindak pidana)

2) Segi obyektif, adalah segi yang berhubungan/berkenan dengan tindakan itu sendiri.

Menurut Van Apelldoorn, bahwa ditinjau dari segi obyektif, maka pidana adalah suatu tindakan (berbuat atau lalai berbuat) yang bertentangan dengan hukum positif. Jadi terkandung sifat yang menimbulkan akibat yang oleh hukum

27 S R, Sianturi. dan E Y, Kanter. (2002). Asas-Asas Hukum Pidana Di Indonesia dan Penerapannya, Jakarta: Strori Grafika, h. 208.

28 Tresna. (1959). Asas-Asas Hukum Pidana, Jakarta: Tiara Limited, ,h. 27. 
dilarang dengan ancaman hukuman. Unsur yang perlu sekali dalam peristiwa pidana (ditilik dari segi obyektif) adalah sifat tanpa hak (onrechtmatidheld), yakni sifat melanggar hukum. Dimana tak terdapat unsur tanpa hak, tak ada peristiwa pidana. ${ }^{29}$

Namun yang sering dipakai dalam setiap Undang-undang Hukum Pidana baik itu dalam KUHP maupun Undang-undang diluar KUHP adalah menggunakan istilah tindak pidana. Sebelum menentukan suatu perbuatan merupakan tindak pidana, terlebih dahulu harus dirumuskan unsur-unsur yang mendukung perbuatan tersebut, sehingga dapat disebutkan sebagai tindak pidana. Istilah "Strafbaar feit" merupakan istilah resmi dalam "wetbook van strafrecht" dalam Kitab Undang-undang Hukum Pidana dikenal dengan sebutan "tindak pidana"

Tindak pidana dapat terjadi kapan saja, dimana saja dan oleh siapa saja atau dapat menimpa siapa saja termasuk dapat saja terjadi di dalam lingkup rumah tangga yang dilakukan oleh orang-orang yang masih ada hubungan dekat baik karena adanya hubungan darah, perkawinan, persusuan, pengasuhan dan perwalian, yang menetap dalam rumah tangga atau hubungan lain bersifat "domestik personal", misal karena yang bersangkutan bekerja membantu rumah tangga dan menetap dalam rumah tangga tersebut.

Tindak pidana yang terdapat dalam UUPKDRT, pada Pasal 5 menyebutkan Setiap orang dilarang melakukan kekerasan dalam rumah tangga terhadap orang dalam lingkup rumah tangganya, dengan cara :
a) kekerasan fisik
b) kekerasan psikis
c) kekerasan seksual, atau
d) penelantaran rumah tangga

29 Apelldoorn, Van. (1975). Pengantar Ilmu Hukum, Cet. XIII, Jakarta: Pradnya Paramitha, h. 338.
Kekerasan fisik adalah perbuatan yang mengakibatkan rasa sakit, jatuh sakit atau luka berat (Pasal 6), Kekerasan psikis adalah perbuatan yang mengakibatkan ketakutan, hilangnya rasa percaya diri, hilangnya kemampuan untuk bertindak, rasa tidak berdaya, dan/ atau penderitaan psikis berat pada seseorang (Pasal 7), Kekerasan seksual sebagaimana dimaksud dalam Pasal 5 huruf c meliputi :

1) pemaksaan hubungan seksual yang dilakukan terhadap orang yang menetap dalam lingkup rumah tangga tersebut

2) pemaksaan hubungan seksual terhadap salah seorang dalam lingkup rumah tangganya dengan orang lain untuk tujuan komersial dan/ atau tujuan tertentu (Pasal 8).

Penelantaran rumah tangga sebagaimana dimaksud dalam Pasal 5 huruf d meliputi :

1) UUPKDRT pada Pasal 9 ayat (1) yaitu : menelantarkan orang dalam lingkup rumah tangganya padahal menurut hukum yang berlaku baginya atau karena persetujuan atau perjanjian ia wajib memberikan kehidupan, perawatan atau pemeliharaan kepada orang tersebut.

2) UUPKDRT pada Pasal 9 ayat (2) yaitu : mengakibatkan ketergantungan ekonomi dengan cara membatasi dan/atau melarang untuk bekerja yang layak di dalam atau di luar rumah sehingga korban berada di bawah kendali orang tersebut.

Tindak pidana kekerasan dalam rumah tangga yang merupakan kekerasan fisik, meliputi :

1) Pasal 44 ayat (1) UUPKDRT Setiap orang yang melakukan perbuatan kekerasan fisik dalam lingkup rumah tangga sebagaimana dimaksud dalam 
Pasal 5 huruf a dipidana dengan pidana penjara paling lama 5 (lima) tahun atau denda paling banyak Rp. 15.000.000,- (lima belas juta rupiah)

2) Pasal 44 ayat (2) UUPKDRT

Dalam hal perbuatan sebagaimana dimaksud pada ayat (1) mengakibatkan korban mendapat jatuh sakit atau luka berat, dipidana dengan pidana penjara paling lama 10 (sepuluh) tahun atau denda paling banyak Rp. 30.000.000,- (tiga puluh juta rupiah).

3) Pasal 44 ayat (3) UUPKDRT

Dalam hal perbuatan sebagaimana dimaksud pada ayat (2) mengakibatkan matinya korban, dipidana dengan pidana penjara paling lama 15 (lima belas) tahun atau denda paling banyak $\mathrm{Rp}$. 45.000.000,- (empat puluh lima juta rupiah).

4) Pasal 44 ayat (4) UUPKDRT

Dalam hal perbuatan sebagaimana dimaksud pada ayat (1) dilakukan oleh suami terhadap isteri atau sebaliknya yang tidak menimbulkan penyakit atau hubungan untuk emnjalankan pekerjaan jabatan atau mata pencaharian atau kegiatan sehari-hari, dipidana dengan pidana penjara paling lama 4 (empat) bulan atau denda paling banyak Rp. 5.000.000,- (lima juta rupiah).

Menurut Pasal 51 UUPKDRT bahwa tindak pidana kekerasan fisik sebagaimana dimaksud dalam Pasal 44 ayat (4) merupakan delik aduan. Tindak pidana kekerasan dalam rumah tangga yang merupakan kekerasan psikis, meliputi :

1) Pasal 45 ayat (1) UUPKDRT

Setiap orang yang melakukan perbuatan kekerasan psikis dalam lingkup rumah tangga sebagaimana dimaksud dalam Pasal 5 huruf $b$ dipidana dengan pidana penjara paling lama 3 (tiga) tahun atau denda paling banyak Rp. 9.000.000,- (sembiian juta rupiah)

2) Pasal 45 ayat (2) UUPKDRT

Dalam hal perbuatan sebagaimana dimaksud pada ayat (1) dilakukan oleh suami terhadap istri atau sebaliknya yang tidak menimbulkan penyakit atau halangan untuk menjalankan pekerjaan jabatan atau mata pencaharian atau kegiatan sehari-hari dipidana dengan pidana penjara paling lama 4 (empat) bulan atau denda paling banyak Rp. 3.000.000,- (tiga juta rupiah).

Menurut Pasal 52 UUPKDRT kekerasan psikis sebagaimana dimaksud dalam Pasal 45 ayat (2) merupakan delik aduan. Tindak pidana kekerasan dalam rumah tangga yang merupakan kekerasan seksual, meliputi :

1) Pasal 46 UUPKDRT

Setiap orang yang melakukan perbuatan kekerasan seksual sebagaimana dimaksud dalam Pasal 8 huruf a dipidana dengan pidana penjara paling lama 12 (dua belas) tahun atau denda paling banyak Rp.36.000.000,(tiga puluh enam juta rupiah).

Menurut Pasal 53 UUPKDRT, tindak pidana kekerasan seksual sebagaimana dimaksud dalam Pasal 46 yang dilakukan oleh suami terhadap isteri atau sebaliknya merupakan delik aduan.

2) Pasal 47 UUPKDRT

Setiap orang yang memaksa orang yang menetap dalam rumah tangganya melakukan hubungan seksual sebagaimana dimaksud dalam Pasal 8 huruf b dipidana dengan pidana penjara paling 
singkat 4 (empat) tahun dan dipidana penjara paling lama 15 (lima belas) tahun atau denda paling sedikit Rp. 12.000.000,(dua belas juta rupiah) atau denda paling banyak Rp. 300.000.000,(tiga ratus juta rupiah).

3) Pasal 48 UUPKDRT

Dalam hal perbuatan sebagaimana dimaksud dalam Pasal 46 dan Pasal 47 mengakibatkan korban mendapat luka yang tidak memberi harapan akan sembuh sama sekali, mengalami gangguan daya pikir atau kejiwaan sekurang-kurangnya selama 4 (empat) minggu terus menerus atau 1 (satu) tahun tidak berturut-turut, gugur atau matinya janin dalam kandungan atau mengakibatkan tidak berfungsinya alat reproduksi dipidana dengan pidana penjara paling singkat 5 (lima) tahun dan pidana penjara paling lama 20 (dua puluh) tahun atau denda paling sedikit Rp. 25.000.000,- (dua puluh lima juta rupiah) dan denda paling banyak Rp. 500.000.000,- (lima ratus juta rupiah).

Tindak pidana kekerasan dalam rumah tangga yang merupakan penelantaran rumah tangga, meliputi :

1) menelantarkan orang lain dalam lingkup rumah tangganya sebagaimana dimaksud dalam Pasal 9 ayat (1) dipidana dengan pidana penjara paling lama 3 (tiga) tahun atau denda paling banyak Rp. 15.000.000,- (lima belas juta rupiah).

2) menelantarkan orang lain sebagaimana dimaksud dalam Pasal 9 ayat (2) dipidana dengan pidana penjara paling lama 3 (tiga) tahun atau denda paling banyak Rp. 15.000.000,- (lima belas juta rupiah).

\section{Konsistensi Legal Spirit UUPKDRT Dan Penyelesaian Peradilan Pada Umumnya}

Usaha penanggulangan kejahatan melalui pembuatan undang-undang (hukum) pidana pada hakikatnya juga merupakan bagian integral dari usaha perlindungan masyarakat (social defence) dan usaha mencapai kesejahteraan masyarakat (social welfare). Dengan demikian, wajar pulalah apabila kebijakan atau politik hukum pidana juga merupakan bagian integral dari kebijakan atau politik sosial (sosial policy). Kebijakan sosial dapat diartikan sebagai segala usaha yang rasional untuk mencapai kesejahteraan masyarakat dan sekaligus mencakup perlindungan masyarakat. ${ }^{51}$

Kebijakan hukum pidana sangat erat kaitannya dengan penegakan hukum. Dalam hal ini arti penegakan hukum itu sendiri adalah suatu proses untuk mewujudkan keinginan-keinginan hukum menjadi kenyataan, yang disebut sebagai keinginan-keinginan hukum disini adalah pikiran-pikiran badan pembuat undang-undang yang dirumuskan dalam peraturan-peraturan hukum itu. Dengan demikian perumusan pikiran pembuat hukum yang dituangkan dalam peraturan hukum akan menentukan bagaimana penegakan hukum itu dijalankan. ${ }^{52}$ Dalam hal ini peranan peraturan hukum sangat besar kaitannya dengan pelaksanaan peraturan hukum yang dilakukan oleh aparat penegak hukum.

Antisipasi kekerasan terhadap perempuan telah banyak dilakukan baik oleh kelembagaan formal (pemerintah) maupun kelembagaan informal (LSM, Organisasi Masyarakat maupun Organisasi Politik). Upaya yang

51 Arif, Barda Nawawi. (2008). Bunga Rampai Kebijakan Hukum Pidana, Jakarta: Kencana Prenada Media Group, h. 27.

52 Raharjo, Satjipto. (2005). Masalah Penegakan Hukum Suatu Tinjauan Sosiologis, Bandung,: Sinar Baru, h. 24. 
dilakukan untuk mencapai kesetaraan dan keadilan gender dalam rangka menghilangkan kekerasan terhadap perempuan dilakukan dengan mengelaborasi realitas sosial, sebagai hasil konstruksi fakta sosial yang diciptakan oleh nilai patriarki. Kondisi kultur patriarki saat ini sudah mulai banyak digugat, mulai dari interpretasi kembali nilai sosial budaya dan cara penafsiran nilai agama. Hasilnya menunjukkan adanya kelompok yang pemahaman gendernya sudah memadai, sehingga berpengaruh terhadap antisipasi kekerasan.

Upaya yang dilakukan sekarang sudah sesuai melalui proses pelembagaan seperti dilakukan pada obyektivikasi Undang-Undang No. 23 tahun 2004 tentang PKDRT (Penghapusan Kekerasan dalam Rumah Tangga). Pada aspek pola relasional masih terjadi praktik-praktik hubungan sosial yang mengedepankan faktor kekuasaan secara fisik (power) atau kekuasaan kewenangan yang mengatur hubungan atasan dan bawahan secara diskriminatif, seperti terjadi pada buruh pekerja, pembantu rumah tangga atau pada keluarga yang dapat bermuara pada kekerasan.

Undang-undang PKDRT telah merumuskan berbagai bentuk perlindungan terhadap perempuan dari KDRT termasuk ancaman pidana terhadap pelaku, namun mengingat kompleksitas dari kasus tersebut pemberlakuan UUPKDRT tidak sertamerta dapat diterapkan. ${ }^{53}$ Realitanya banyak kasus yang dicabut kembali oleh korban pada tahap penyidikan. KDRT yang terjadi dewasa ini bukan saja menimbulkan perempuan sebagai korban namun juga anak-anak. Pengadilan negeri merupakan suatu lembaga pada peradilan umum yang memeriksa dan memutuskan

${ }^{53}$ Toule, E. R. M. (2016). Analisis Tentang Penjatuhan Pidana Bersyarat Terhadap Perkara Kekerasan Dalam Rumah Tangga, Jurnal Belo Bagian Hukum Pidana Fakultas Hukum Unpatti dan MAHUPIKI, Vol.I No.1. serta menyelesaikan perkara-perkara termasuk perkara KDRT merupakan tempat bagi masyarakat (korban KDRT) untuk mencari keadilan.

Hakim dalam hal penerapan peraturan sebagai kebijakan aplikatif dapat menjatuhkan pidana lebih adil, manusiawi dan mempunyai rambu-rambu yang bersifat yuridis, moral justice dan sosial justice. Konkritnya, konsekuensi logis aspek ini maka putusan hakim atau putusan pengadilan diharapkan lebih mendekatkan diri pada keadilan yang mencerminkan nilai-nilai yang hidup di masyarakat. Hakim dalam mengaktualisasikan tujuan dari UUPKDRT melindungi korban KDRT, menindak pelaku KDRT namun disatu sisi juga hakim diperhadapkan dengan konsekuensi perceraian bila menjatuhkan pidana yang tidak sesuai dengan apa yang dikehendaki oleh pembentuk undang-undang yakni keutuhan rumah tangga.

\section{P E N U T U P}

UUPKDRT mencegah segala bentuk kekerasan terutama kepada perempuan, memberikan perlindungan kepada korban KDRT, menindak pelaku KDRT namun juga menjaga keutuhan rumah tangga yang harmonis dan sejahtera. Banyak kasus KDRT yang dilaporkan namun tidak sedikit juga yang dicabut oleh korban dengan berbagai alasan, seperti masih mencitai pelaku, pelaku merupakan pencari nafkah dalam rumah tangga.

Penyelesaian kasus KDRT ada juga sampai pada putusan pengadilan, namun hal ini tentunya membawah konsekuensi dari tujuan UUPKDRT tersebut. Meskipun pencegahan segala bentuk KDRT, melindungi korban, menindak pelaku tercapai namun jika kasus tersebut diteruskan sampai pada putusan pengadilan apakah tujuan menjaga keutuhan rumah tangga yang harmonis dan sejahtera dapat tercapai. 
Penyelesaian KDRT membutuhkan kearifan dari penegak hukum (polisi, jaksa dan hakim)

KDRT dengan alasan apapun dari waktu ke waktu akan berdampak terhadap keutuhan keluarga, yang pada akhirnya bisa membuat keluarga berantakan. Jika kondisinya demikian, yang paling banyak mengalami kerugian adalah anak-anaknya terlebih bagi masa depannya. Karena itulah perlu terus diupayakan mencari jalan terbaik untuk menyelamatkan institusi keluarga dengan tetap memberikan perhatian yang memadai untuk penyelamatan terutama anggota keluarga, dan umumnya masyarakat sekitarnya. Adapun saran yang dapat diberikan adalah aparat penegak hukum agar lebih arif dan bijkasana, khusus bagi hakim dapat menerapkan pidana bersyarat terhadap pelaku KDRT.

\section{DAFTAR PUSTAKA}

Apelldoorn, Van. (1975). Pengantar Ilmu Hukum, Cet. XIII, Jakarta: Pradnya Paramitha.

Arief, Barda Nawawi. (1998). Beberapa Aspek Kebijakan Penegakan dan Pengembangan Hukum Pidana, Bandung: Citra Aditya Bakti.

Arief, Barda Nawawi. (2007). Masalah Penegakan Hukum dan Kebijakan Hukum Pidana dalam Penanggulangan Kejahatan, Jakarta: Kencana.

Arif, Barda Nawawi. (2008). Bunga Rampai Kebijakan Hukum Pidana, Jakarta: Kencana Prenada Media Group.

Bentham, Jeremy. (2006). Teori Perundang-Undangan

Prinsip-Prinsip Legislasi, Hukum Perdata dan Hukum Pidana, Bandung: Penerbit Nusamedia \& Penerbit Nuansa.

Gosita, Arif. (1993). Masalah Korban Kejahatan, Jakarta: Akademika Pressindo.
Hamzah, Andi. (1986). Perlindungan Hak-Hak Asasi Manusia dalam Kitab Undang-Undang Hukum Acara Pidana, Bandung: Binacipta.

Moeljatno. (1955). Perbuatan Pidana dan Pertanggungjawaban Pidana, Yogyakarta: Badan Penerbit Gajah Mada.

Mansur, Dikdik. M. Arief. (2007). Urgensi Perlidungan Korban Kejahatan Antara Norma dan Realita, Jakarta: RajaGrafindo Persada.

Packer, Herbert L. (1968). The Limits of Criminal Sanction.

Raharjo, Satjipto. (2005). Masalah Penegakan Hukum Suatu Tinjauan Sosiologis, Bandung,: Sinar Baru.

Schafer, Stephen. (1968). The Victim and Criminal, Random House, New York.

Situmorang, Victor. (1988). Kedudukan Wanita Di Mata Hukum, Jakarta: Bina Aksara.

S R, Sianturi. dan E Y, Kanter. (2002). Asas-Asas Hukum Pidana Di Indonesia dan Penerapannya, Jakarta: Strori Grafika.

Soeroso, Moerti Hadiati. (2010). Kekerasan Dalam Rumah Tanggga (Dalam Perspektif Yuridis-Kriminologi), Jakarta: Sinar Grafika.

Tresna. (1959). Asas-Asas Hukum Pidana, Jakarta: Tiara Limited.

\section{Lain-Lain}

Toule, E. R. M. (2016). Analisis Tentang Penjatuhan Pidana Bersyarat Terhadap Perkara Kekerasan Dalam Rumah Tangga, Jurnal Belo Bagian Hukum Pidana Fakultas Hukum Unpatti dan MAHUPIKI, Vol.I No.1. 